\title{
Healthcare networks: trends of knowledge development in Brazil
}

\author{
Redes de atenção à saúde: tendências da produção de conhecimento no Brasil \\ Redes de atención a la salud: tendencias de la producción de conocimiento en Brasil
}

\begin{abstract}
Caroline Cechinel Peiter ${ }^{1}(1)$ José Luís Guedes dos Santos ${ }^{1}(\mathbb{D}$ Gabriela Marcellino de Melo Lanzoni ${ }^{1}$ (C) Ana Lúcia Schaefer Ferreira de Mello ${ }^{1}$ (D) Maria Fernanda Baeta Neves Alonso da

Costa $^{1}$

Selma Regina de Andrade ${ }^{1}$
\end{abstract}

1. Universidade Federal de Santa Catarina.

Florianópolis, SC, Brasil.
Corresponding author:

Caroline Cechinel Peiter.

E-mail: carolcechinel@gmail.com.

Submitted on $07 / 28 / 2018$

Accepted on 11/20/2018.

DOI: 10.1590/2177-9465-EAN-2018-0214

\section{Abstract}

Objective: To analyze the trend of scientific production about Healthcare Networks in thesis and dissertations in Brazil. Methods documental, descriptive and exploratory study, with a quantitative approach, on the published between 2013 and 2016. The data collection was based on the catalog of theses and dissertations of Brazilian Personnel Improvement Coordination of Superior Level, during January 2018. Results: The 190 papers founded were distributed in four main classes: Integrated Healthcare Networks Management; Thematic health networks; Primary Healthcare as network Ordinator; and Professional education in healthcare networks. Conclusion: It is trend in the scientific knowledge production the study of Primary Healthcare as the ordinator of network and its interface with the other levels, the professional education in healthcare networks, the continuing education in health, focused on the healthcare networks management.

Keywords: Unified Health System; Health Management; Health Care Levels; Continuity of Patient Care; Comprehensive Health Care.

\section{Resumo}

Objetivo: Analisar a tendência de investigação de teses e dissertações brasileiras da área da saúde sobre o tema Redes de Atenção à Saúde. Método: Estudo documental, descritivo e exploratório de abordagem quantitativa, realizado a partir da base de dados Catálogo de Teses e Dissertações da Coordenação de Aperfeiçoamento de Pessoal de Nível Superior. A coleta de dados se deu em janeiro de 2018, a partir do termo "Rede de Atenção à Saúde". Foram incluídas teses e dissertações da área da saúde, desenvolvidas no cenário brasileiro e defendidas entre os anos 2013 a 2016. Resultados: Os 190 trabalhos encontrados foram distribuídos em quatro classes principais: Gestão das Redes de Atenção à Saúde; Redes temáticas de Atenção à Saúde Atenção Primária à Saúde como ordenadora da rede; e Formação profissional para atuação em rede. Conclusão: São tendências da produção do conhecimento o estudo da atenção primária como ordenadora da rede e sua relação com os demais níveis, a formação dos profissionais para atuação articulada e integrada, e a educação permanente em saúde, com foco na gestão das redes de atenção à saúde.

Palavras-chave: Sistema Único de Saúde; Gestão em Saúde; Níveis de Atenção à Saúde; Continuidade da Assistência ao Paciente; Assistência Integral à Saúde.

\section{Resumen}

Objetivo: analizar la tendencia de investigación de tesis y disertaciones brasileñas del área de la salud sobre el tema Redes de Atención a la Salud. Método: estudio documental, descriptivo y exploratorio de abordaje cuantitativo, realizado a partir de la base de datos Catálogo de Tesis y Disertaciones Coordinación de Perfeccionamiento de Personal de Nivel Superior. La recolección de datos fue realizada en enero de 2018, a partir del término "Red de Atención a la Salud". Se han incluido tesis y disertaciones del área de la salud, desarrolladas en el escenario brasileño y defendidas entre los años 2013 a 2016. Resultados: Los 190 trabajos se distribuyeron en cuatro clases principales: Gestión de las Redes de Atención a la Salud; Redes temáticas de Atención a la Salud; Atención Primaria a la Salud como ordenadora de la red; y Formación profesional para actuación en red. Conclusión: Son tendencias de la producción del conocimiento, el estudio de la atención primaria como ordenadora de la red y su relación con los otros niveles, la formación de los profesionales para actuación en red articulada y integrada, y la educación permanente en salud, con foco en la gestión de las redes de atención a la salud.

Palabras clave: Sistema Único de Salud; Gestión en Salud; Niveles de Atención de Salud; Continuidad de la Atención al Paciente; Atención Integral a la Salud. 


\section{INTRODUCTION}

The organization of health systems can vary between a conjuncture of total fragmentation and even the complete integration of its components, transiting among many possibilities for arrangements between the two extremes of this spectrum, which impacts on the characteristics of the health care models adopted. In general, fragmented systems are bound to health care models which respond to the acute conditions, whereas integrated systems are linked with health care models to the chronic conditions. ${ }^{1}$

The change in the epidemiological, demographic, nutritional and technological pictures has resulted in the current profile of healthcare situation of the population, with triple burden of illness, characterized by the co-occurrence of chronic and acute conditions, added even to the grievances associated with external causes. Thus, it is necessary to implement health care models that can respond appropriately to the chronic conditions. In view of this new program, many countries have been reformulating their healthcare systems in the last years, redirecting them to an integrated structure, focusing on reinforcing the Primary Health Care $(\mathrm{PHC})$ and the comprehensive care. ${ }^{2}$

In Brazil, the Unified Health System (UHS), organized by establishing the Integrated Healthcare Networks (IHN), seeks to qualify the care by increasing access to and longitudinality of care, with the objective of reach of integrality. ${ }^{3-4}$ In the IHN, the population, the operational structure and the health care models must be defined to respond promptly to acute events as well as to manage chronic health conditions. ${ }^{1} \mathrm{IHN}$ are designed in a way to centralize the care coordination and networks ordination in the $\mathrm{PHC}$, seeking to provide an ongoing coordinated of actions and health care services from a territorially defined population. This form of organization value the inter organizational communication flows, starting from a more hierarchical model to achieve an integrated relationship among the elements of its operational structure, among them the secondary and tertiary points of attention, support systems and PHC..$^{4-5}$ In this way, they seek integration among the points of attention, in order to improve the comprehensive care ${ }^{1}$.

The implementation of IHN in the Brazilian UHS is still in the consolidation and discussion process of strategies aiming at its full deployment, ${ }^{3,5}$ which has encouraged the conduct of scientific researches about that theme. ${ }^{6}$ The $\mathrm{IHN}$, as regulatory and organizers of a health care model, present an ideological, discursive matrix, which structure them, so that the scientific production on this theme can be considered as possible reverberations, effects and visibilities of building a reality of the services and practices in health routine. Given this conjuncture, it has been questioned: what is the trend in the investigation about the theme Integrated Healthcare Networks in the scientific productions in the health area in Brazil?

The objective of this study was to analyze the trend in the investigation of Brazilian theses and dissertation of the health area about the theme Integrated Healthcare Networks.

\section{METHOD}

It is a qualitative, descriptive and exploratory study, of documentary base, carried out from Database Theses and Dissertations of the Coordination for the Improvement of Higher Education Level (CAPES), ${ }^{7}$ linked to the Brazilian Ministry of Education.

The data collection occurred in January 2018, on the site of CAPES that make available the Catalog, under a public domain regime. The term "Integrated Healthcare Network" into the search field was used, applying the filter "Health Sciences" on the Large Knowledge Area field. Exclusion criteria included: thesis or dissertation in the field of health, developed in the Brazilian landscape, defended from 2013 to 2016 . Studies that do not provide the abstract, or that do not present the term Healthcare Network in the title or abstract was not incorporated into the initial search due to provide the term in the name of the line or project of research to which were bound.

Time delimitation established aimed at addressing the last quadrennium of the evaluation of the CAPES. Further, it is considered that this temporal cut enabled the inclusion of productions developed on the basis of normative and contextual devices after the year 2010, bearing in mind the publication of Ordinance no. 4.279, on 30 December 2010. Since 2011, the IHN, effectively, assume the center of the national policy of healthcare of the $\mathrm{Mi}$ nistry of Health (MS), taking the national debate and redirecting the federal resources that have been available, potentiating the state and municipal resources.

The initial search showed 365 results, of which 288 were linked to the great area of the health sciences. Of these, 220 have been defended in the 2013-2016 quadrennium. Five studies were excluded because they were not made available the abstract in the database and 25 for showing the term Healthcare Network only in the name of the research line or project in which they were linked to. Thus, we achieved a final sample of 190 studies.

The data analysis consisted in extracting information from each thesis or dissertation, considering: Year of defense; Region; Institution; Postgraduate program; Methodological approach; Method; Study context; Research participants; Descriptors/Keywords; and of the abstract the Results and Conclusions. The characterization data were organized in an Excel ${ }^{\circledR}$ software spreadsheet and analyzed through descriptive statistics of variables. The textual material concerning the results and conclusions have been processed using the Interface de R pour les Analyses Multidimensionnelles de Textes et de Questionnaires software (IRAMUTEQ ${ }^{\circledR}$ ).

The IRAMUTEQ allows the processing and statistics analysis of a textual corpus through grouping the words, referred to as occurrences, for semantic similarity. Therefore, it allows five types of analysis: Traditional textual statistics; Search for specificities of groups and confirmatory factor analysis; Descending Hierarchical Classification (DHC); Analyzes of similarity of words; and Word cloud. ${ }^{8-9}$

It is worth mentioning that IRAMUTEQ possesses a unique interface, which differs from the others similar software. Then, 
it is important to describe the meanings of its nomenclature. The corpus comprises the complete textual grouping used in the analysis, which is composed of an assembly of texts. Each text is represented by a unit to be analyzed, which in this study corresponded to each abstract included in the analysis. The texts are, further, divided by the software into Text Segments (TS), fragments of texts of about three lines delineated by semantic similarity. ${ }^{8-9}$

The corpus has been prepared based on the texts unification, composed of the portions of result and conclusion of each abstract of the work selected, organized in an archive of the Open Office ${ }^{\circledR}$ program. The material was revised to eliminate possible typing errors and standardize acronyms, allowing different terms, but with the same meaning, to be considered in the analysis as similar. The following terms were standardized: Integrated Healthcare Network, Primary Healthcare, Family Health Strategy, Mobile Emergency Care Service (SAMU), Unified health system, mental health and pharmaceutical services. Composite terms with more than one word were rewritten, separated with subscribed dash, be they identified as a single term. In addition, the terms Basic Care and Primary Care to/in Health have been replaced by Primary Health Care, considering the equivalence of terms defined by the Brazilian National Basic Health Care Policy ${ }^{10}$, allowing larger consistency of data.

The categories of words included for analysis were the following: adjectives, nouns, verbs and non-recognized forms, as they included frequent terms in the corpus, such as acronyms and unified terms, so that $91.3 \%$ of TS were utilized for the analysis. Classical textual statistics analysis and DHC were used for this study. The occurrences showed in each one of the classes in the DHC are sorted in descending order according to Chi-square test $\left(X^{2}\right)$, and all of them showed statistically significant values $(p<0.0001)$.

\section{RESULTS}

Of the 190 studies selected, 153 (80.5\%) were master dissertations and 37 (19.5\%), PhDTheses, which characterization is shown in Table 1.

The 190 studies presented 809 keywords and 394 different terms. The most common keywords were: Primary Health Care $(54 ; 28.4 \%)$, Nursing (29;15.3\%), Family Health Strategy (23;12.1\%), Unified Health System (20;10.5\%), Health Care Services $(15 ; 7,9 \%)$, Evaluation in Health $(14 ; 7.4 \%)$ and Comprehensive Health Care (14;7.4\%).

Regarding the textual data analysis, the general corpus consisted of 188 texts, since it was not possible to clearly identify in two abstracts the results and/or conclusions of the research. In these, 38,531 occurrences have emerged, of which 5,284 were distinct words. The classic textual statistical analysis evidenced as the most frequent terms, in descending order: health, service, care, attention, professional, network, Integrated Healthcare Network, Primary Health Care, work and process, showing itself, overall, like the frequency of keywords.

From the analyzed material, five semantic classes were identified: 1) Integrated Healthcare Networks Management; 2) Thematic Integrated Healthcare Networks; 3) PHC as ordering of network; 4) Professional training for acting in network; 5) Statistical results. The analysis by $\mathrm{DHC}$ evidenced relationships between the Classes 1 and 4 and Classes 3 and 2. Both groupings are permeated by the Class 5, which corresponded to statistics inferences of the epidemiological results and aspects of the studies, which will not be discussed in this article since it did not represent thematic trend of investigation. The Figure 1 illustrates the distribution and relationship between the classes.

The Class 1, Integrated Healthcare Networks Management, incorporated $24.9 \%$ of TS and was to highlight the Model, Actor, Process, Management and Work occurrences. In this class, it was highlighted the need of the care model reorientation to reach the IHN assumptions. Even though studies indicate the $\mathrm{PHC}$ such as restructuring axis of the health care model (as shown in the class 3 ), it was found that the predominant models are little active in health promotion actions. Recurrent content regarding the fragility of the collective responsibility and of the different knowledges related to health practice point to the need to reorganize the work process of the multi-professional teams, since the coordination of the care by the PHC is sustained, necessarily, by actions shared with many professionals. There was also highlighted the networks orientation by national policies, allowing its strengthening through the appropriate implementation by their actors: professionals, managers and users. Despite showing the importance of the dialogue among teams, managers and users for consolidation of a model of attention to chronic conditions, the studies have found deficiencies of social participation. Low managerial capacity of the municipalities has been identified, constituting an isolated obstacle for the limited care capacity installed of small-size municipalities. Added to this, there is difficulty to plan inter municipal actions, including shared financing and making-decision process.

The Class 2 was named Thematic Integrated Healthcare Networks, represented by $16.8 \%$ of TS. In this class, the term Child was the most significant. Furthermore, themes related to the integrated maternal and child healthcare networks have been highlighted (including the birth and childbirth process, premature babies, neonates and adolescents), hearing health, and care of people with chronic diseases. Content addressed aspects related to the importance of the professional positioning, which will be able to determine the care profile of the health service: either addressed to the care fragmentation or to its integrality.

In view of the thematic networks, the low interaction among the networks services has been indicated, showing failures in referencing the specialized services, reflections of a hegemonic medical-healthcare model, hospital and disease-centered, still present. The need of actions that articulate health promotion to care practices was highlighted, based on self-care and participation of the multi-professional team, user e relatives for a shared care.

The Class 3, PHC as the network ordinator, obtained the largest frequency of TS, with $27.1 \%$, and highlighted the 
Table 1. Characterization of Brazilian theses and dissertations of the health area with the thematic Integrated Healthcare Networks defended between 2013 and $2016(n=190)$.

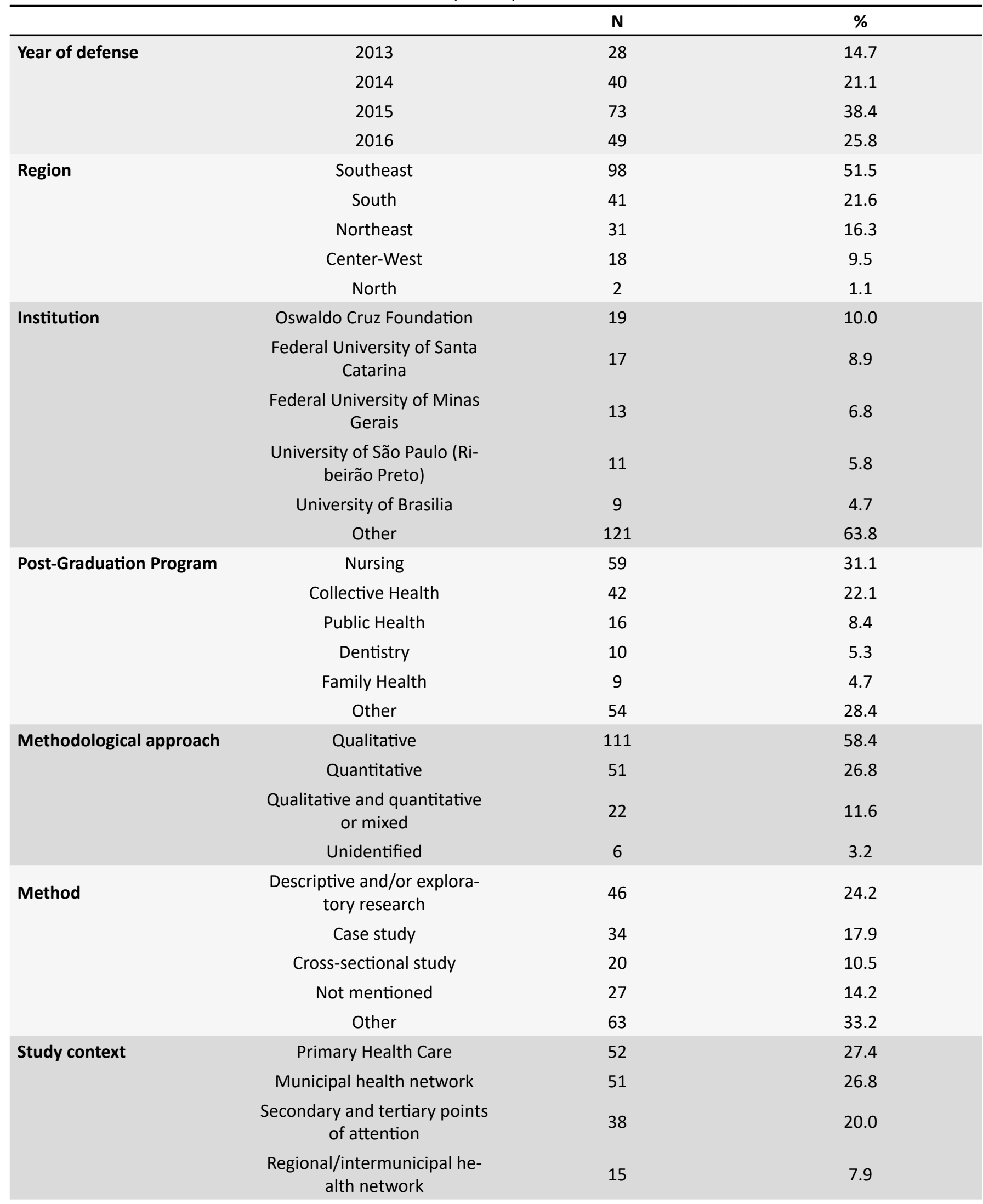




\begin{tabular}{lccc}
\hline & N & \% \\
\hline National health network & 13 & 6.8 \\
State health network & 10 & 5.3 \\
Higher Education Institutions & 8 & 4.2 \\
Support systems & 1 & 0.5 \\
Research participants & Other & 2 & 1.1 \\
& Professionals & 59 & 31.0 \\
Users and relatives & 32 & 16.8 \\
Users, professionals and ma- & 18 & 9.4 \\
nagers & 17 & 8.9 \\
Managers & 16 & 8.4 \\
Professionals and managers & 13 & 6.8 \\
Users and professionals & 6 & 3.5 \\
Teachers and students & 1 & 0.5 \\
Users and managers & 18 & 9.4 \\
Other & 10 & 5.3
\end{tabular}

occurrences Access and Service. In this class, the distance and the fragility in the integration among the different health services were recurrent, with emphasis on the incipience of the logistical systems. The non-effective communication among all the levels of care was identified as an obstacle to the monitoring of the user throughout the network. In the secondary and tertiary points of attention, the studies have indicated slowness regarding the performance of complementary tests and in the evaluation by other professionals. In the urgency and emergency services, the indication of demands that could be absorbed by the PHC has been frequent. The studies analyzed have still brought the need to restructure the PHC which, since consolidated, becomes the priority gateway to other services, enabling it to assume its central role in the network organization.

The Class 4, Professional training for acting in network professional, had $18.3 \%$ of TS and showed an interface with the Class 1, indicating interest on the perspective of the Continuing Education as Health Policy and, therefore, management on health device, concern in the development of the competence of RAS management in the professional training and the need. In this context, the Continuing education is adopted as a tool to strengthen the commitment and preparation of professionals and managers about the networks management. The texts presented content related to the need to reorient the training, with focus on the integrality, since they consider the current model far from the ideal to professional training for the SUS. Strategies such as the matrix support performed by the specialized professionals are also indicated (which, despite still show low structured articulations), assure specialized rearward for professionals and enable a differentiated learning matrix that aggregate the change of multi professional knowledges to the continuous care production. There were still suggested the learning-service integration in the intersectorial spheres of management and Continuou education in health as a tool to realize changes and generate transformations.

\section{DISCUSSION}

The institution of the Ordinance no. 4,279 of 2010, which states the IHN in the field of UHS in Brazil, resulted in an increase of discussions and investigations about the thematic, which may have contributed for progression in the number of studies from 2013 to $2015 .{ }^{3}$ Consult to the Dissertations and Theses Catalog of CAPES showed that, in 2017, 84 theses and dissertations have been defended about the theme. This number is higher in comparison with previous years and shows the expansion of the researches about the thematic $\mathrm{IHN}{ }^{7}$

It was noted dispersion of works, since the 190 theses and dissertations were developed in 126 institutions. However, we noted concentration of studies in the Southeast region, with $51.5 \%$ of theses and dissertations defended in the period. These data corroborate the irregular national distribution of master's and doctoral degrees courses. Study that aimed to analyze the stricto sensu post-graduation distribution in Brazil has identified that $50.7 \%$ of master's and doctoral degrees courses are concentrated in the Southeast of the country, ${ }^{11}$ of doctoral degree in Nursing $(50.0 \%)$ and research groups $(49.5 \%)$ that are also concentrated in the Southeast of the country. ${ }^{11-12}$

Regarding the post-graduation program of the origin of the studies, the highlights were the Nursing and Collective Health. In the UHS context, the redefinition of the identity through the nurse's autonomy and empowerment was greatly driven by the creation of the Family Health Strategy (FHS). After that, with the strengthening of the UHS and FHS consolidation, the demands 


\section{Integrated Healthcare Networks in the theses and dissertations of the health area}

\begin{tabular}{|c|c|c|c|c|}
\hline $\begin{array}{c}\text { Class } 3 \\
(27.1 \%)\end{array}$ & $\begin{array}{c}\text { Class 2 } \\
(16.8 \%)\end{array}$ & $\begin{array}{l}\text { Class } 1 \\
(24.9 \%)\end{array}$ & $\begin{array}{c}\text { Class } 4 \\
(18.3 \%)\end{array}$ & $\begin{array}{l}\text { Class } 5 \\
(12.9 \%)\end{array}$ \\
\hline $\begin{array}{c}\text { APS as } \\
\text { ordering of the } \\
\text { network } \\
\text { Access } \\
\text { Service } \\
\text { Procedure } \\
\text { Door } \\
\text { To carry out } \\
\text { Unit } \\
\text { Entry } \\
\text { Absence } \\
\text { Point } \\
\text { Center } \\
\text { Reference } \\
\text { Basic } \\
\text { Primary Health } \\
\text { Care } \\
\text { Counter references } \\
\text { Demand } \\
\text { Consultation } \\
\text { Treatment } \\
\text { Dengse } \\
\text { Dental Case } \\
\text { Reception } \\
\text { To wait } \\
\text { Clinical } \\
\text { Attention } \\
\text { Classified } \\
\text { Intercurenes }\end{array}$ & $\begin{array}{c}\text { Integrated } \\
\text { Healthcare } \\
\text { Networks } \\
\text { thematics } \\
\text { Child } \\
\text { To live } \\
\text { HIV } \\
\text { Loss } \\
\text { Caregiver } \\
\text { Adolescent } \\
\text { AIDS } \\
\text { Heaning } \\
\text { Familiar } \\
\text { Predetermined } \\
\text { Disease } \\
\text { Prenatal } \\
\text { Member } \\
\text { Effect } \\
\text { To relate } \\
\text { Implication } \\
\text { Chronical } \\
\text { Importance } \\
\text { Establishsd } \\
\text { Phenomenon } \\
\text { Sufforing } \\
\text { Pulmonary } \\
\text { Obstructive }\end{array}$ & 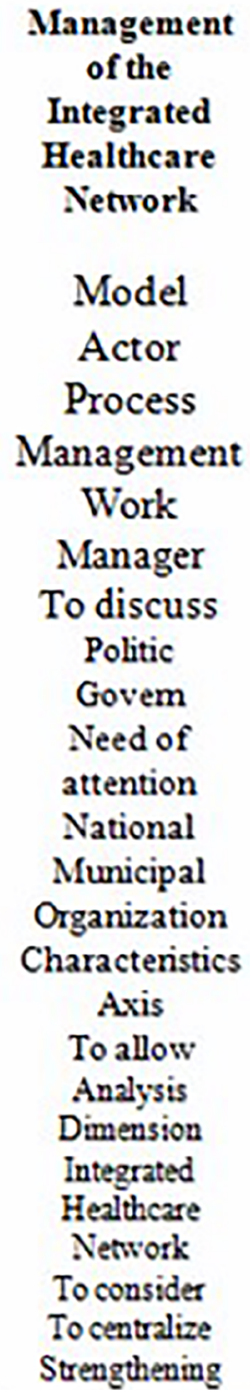 & $\begin{array}{c}\text { Professional } \\
\text { training for } \\
\text { acting in } \\
\text { networks } \\
\text { Training } \\
\text { Scenery } \\
\text { To subject } \\
\text { NASF } \\
\text { Teaching } \\
\text { Movement } \\
\text { Change } \\
\text { Student } \\
\text { Recognizing } \\
\text { Education } \\
\text { University } \\
\text { Potentiality } \\
\text { Nezotistion } \\
\text { Exclusion } \\
\text { Project } \\
\text { To develop } \\
\text { Autonomy } \\
\text { Incorpostion } \\
\text { Possib!e } \\
\text { Integratos } \\
\text { University } \\
\text { Tension } \\
\text { Preconception } \\
\text { To think } \\
\text { Pedsgogical } \\
\text { Mathodology }\end{array}$ & $\begin{array}{c}\text { Statistical } \\
\text { results } \\
\text { Symptom } \\
\text { Major } \\
\text { Minor } \\
\text { Elevated } \\
\text { Value } \\
\text { Rate } \\
\text { To present } \\
\text { Average } \\
\text { Item } \\
\text { Hospitalization } \\
\text { Neonatal } \\
\text { Correlation } \\
\text { Cardiovascular } \\
\text { Number } \\
\text { Percentage } \\
\text { Risk } \\
\text { Prevalence } \\
\text { Version } \\
\text { Northess: } \\
\text { Born } \\
\text { Scale } \\
\text { Depression } \\
\text { Classification } \\
\text { Intern } \\
\text { Region }\end{array}$ \\
\hline
\end{tabular}

of the PHC required greater autonomy and increase in scope of this professional's actuation, which influenced the valuation of this professional's work has intensified, with highlight to its actuation in the services management. Added to this, for having in its academic curriculum disciplines related to the administration, the nurse needs to explore the context and the models of 
attention in which occurs the interaction among the persons. In this way, even if the theme Integrated Healthcare Networks be interdisciplinary and multi-professional, it is characterized as an important niche of interest in acting for Nursing. ${ }^{12}$

The predominance of the production in Nursing can also be interpreted as an alert for the importance of new studies about the theme in other areas in the field of health. The processes of management and work of many professions in the UHS have an interface with the healthcare model, the Integrated Healthcare Networks, and more specifically the Thematic Integrated Healthcare Networks, and it can foster different academic productions.

The production of knowledge in health sciences is supported by means of quantitative and qualitative approaches, sometimes used in an associated manner. The analyzed studies used mostly qualitative approach. Despite the hegemony of quantitative studies in health, the qualitative research gains space as themes relative to human and social sciences are inserted in the investigations, by making of the development of studies with methodological rigor founded on theoretical bases a challenge. ${ }^{13-14}$

Considering the research methods, the use of descriptive and/or exploratory and case study research design predominated. While exploratory and descriptive studies allow to obtain a strong understanding of the investigation phenomena, it is important the research design investment with a large-scale theoreticalmethodological. The use of the case study as methodological reference allows to analyze an institution, a sector, a government program, which enables to represent a peculiar case or compare a set of these. This method is useful in the health area, as enable the investigation of complex phenomena, such as those related to networks of attention, by means of several sources of data collection, allowing its deep understanding. ${ }^{15}$

Most studies was carried out in the APS context and of the municipal health network, showing the UHS coherence principle of political and administrative decentralization with focus on the municipalisation and on the assumption of the $\mathrm{IHN}$ coordination by the PHC. Despite the recommendation that a health network achieves its autonomy and be able to offer the integrality in the three levels of attention in the limits of the health region, ${ }^{1716}$ only $7.9 \%$ of the analyzed studies focused on this context. The strengthening of regional territories demand reflection and discussion on the regional management, to define, collaboratively, access strategies and regional integration, regulatory instruments, and planning and allocation of the offer, aiming to ensure the integrality of attention. .,17 $^{-17}$

Studies included as participants the main actors of the IHN, that is, professionals, users, relatives and managers, beyond educators and professionals in training. This finding meets the national strategy for the IHN implementation with the inclusion of different actors, governmental and social, and their interdependencies, allowing the counterpart of different interests in light of the collective benefit. ${ }^{16}$

The most frequent keywords of the study showed coherence with the most frequent terms, with emphasis on the theme PHC, indicating that the descriptors represent appropriately the results found by the studies. This analysis also shows conformity with the priority lines of investigation on the $\mathrm{IHN}$, which includes $\mathrm{PHC}$ as coordinator of care and integration among the health services. ${ }^{6}$

It is necessary to consider that the changes in the health care models and organizational arrangements occur more slowly than the factors that influenced the chronic conditions increase. In this way, today, for the most part, the chronic conditions are assisted by health care models to acute conditions, ${ }^{1,18}$ justifying the evidenced need in the results of this study of reorientation of the care model, suiting it in order to meet the chronic conditions.

In this way, the collective responsibility, including multi-professional actuation and social participation, is substantial to achieve the IHN objectives. The training of human resources is central point for structuring and integrating of the networks, generating professionals prepared to actuate as protagonists in the system of governance of IHN. ${ }^{19}$ The reorganization of the work of the teams must consider the assumptions of the governance, having as final objective to strengthen the capacity of regional management by means of the planning, monitoring and evaluation. The term governance did not emerge as frequent occurrence in any of the classes of this study, which allow to infer that the use of the term is still incipient in this context. However, it emerged from the results of actions that can be considered strategies of strengthening of the regional governance, such as the capacitation of professionals in networks concepts, foster to evaluation systems of the services quality and the orientation of the municipalities by the health region about a shared planning of health. ${ }^{20}$

Still regarding the IHN management, the incentive to the municipalization in the UHS face problems in the access to the medium and high complexity services, considering the predominance of small-sized municipalities and the normally low capacity installed of these, leading to a common situation of external dependence, specially to the medium and high complexity services. With the aim at relieving these lost, the UHS regulation realized in 2011 aimed to prioritize the ascending, substantial planning in this process. In this conjuncture, the regional integrated health networks are shown as fundamental in the making-decision process and of responsibilities shared among municipalities. ${ }^{21}$

With the aim to promote a networked scale economy, without any loss of integrality, the thematic integrated healthcare networks are defined. In the UHS, the priority thematic networks are: stork network ("stork", mother and child care), psychosocial attention, chronic diseases, urgent and emergency care, and care for people with deficiency. ${ }^{22}$ The highlight of the occurrence child in the analysis of this study and the presence of other terms related meet the Objectives of the Millennium Development, commitment proposed by the Organization of the United Nations and established by the world leaders in the year 2000. In this document, two of the eight objectives addressed the reduction of infant mortality and improvement of the maternal health. ${ }^{23}$ This found trend still indicates, interest of investigation on the Stork Network that, in Brazil, has as focus the maternal health and of children up to two years. ${ }^{24}$ In the woman health context, this network qualified the 
attention to these populations that showed unfavorable health indicators, requiring, thereby, a policy of attention addressed to its specificities. ${ }^{25}$

Healthcare into the logic of the thematic networks is related to the secondary and tertiary points of attention and their specialized services. The conception of points of attention to health comes, in the IHN context, as strategy for remodeling of isolated services and fragments organized into the until existing pyramidal model, indicating the interest in the integrated attention promoted by the thematic networks. ${ }^{26}$

However, the continuity of the care is still a fragility, especially regarding the discontinuous flows of reference and counterreference, ${ }^{27-28}$ low articulation of the points of attention specialized with the PHC and rare effective processes of counterreference. ${ }^{28-29}$ In this way, it can be seen the nurse's actuation space of ligation as strategy to overcome the fragility in the integration between the health services and promotion of the care continuity in the healthcare network. In health services that aimed at improving the communication and care planning among the points of attention, it is possible to promote the actuation of this professional as responsible for the management of information and coordination of care and services. This has been a strategy applied for reaching the integrality and continuity of the link in the flows of the user by the system in other contexts, such as countries as Canada, Spain and Portugal, and has obtained successful results regarding the continuity of the care in points of transition, with focus on the transition of the hospital environment to PHC, sensible moment to the discontinuity of the care. ${ }^{4,30-31}$

The Class 2 conducted himself as complementary to the Class 3 , indicating the association between the thematic networks and its orientation by the PHC. The PHC allocation as coordinator of the care includes the organization of the healthcare provision to patient, managing the resources and devices for distribution of attention among the providers. The absence or incipience of this coordination presupposes difficulty in the access and in the continuity of the care, waste of financial resources, duplication of specialized services and bad quality of attention. ${ }^{2,4}$ However, this problematic is not restricted to the Brazilian reality. Study conducted in ten countries on the longitudinality of the care in the perception of the PHC doctors evaluated as unfavorable the communication with the other providers of services and the coordination of the care by the PHC, being characterized as one of the main obstacles in health systems worldwide. ${ }^{2}$

I view of this, the horizontal and vertical integration of the IHN depends directly on effective mechanisms of communication. ${ }^{3132}$ The limited exchange of information among the points of attention represents a significant limitation to the care coordination, making it difficult to monitor the patient and impairing in many moments its access to the final diagnosis and treatment. ${ }^{5}$ However, the results of the study did not present advances in regard to the technical and logistic support systems of the IHN, emphasizing the immaturity of the implementation of these tools in the UHS.
The last class presented the need a professional training guided towards the assumptions of the IHN, highlighting that the human resources represent fundamental element of the satisfactory healthcare network organization and performance. In this context, the professionals must be capacitated and motivated to work as protagonists in the service, aiming at the networks quality and perfectioning. A case study conducted on the healthcare networks of Brazil and Colombia pointed to the weakness of the professional training in accordance with the model of attention, both regarding the professionals of the PHC and at the other levels of attention. ${ }^{5}$

Furthermore, the temporary contract model and the limited workload influence the professional turnover and creation of links with the population, respectively, and compromise the longitudinality and ongoing of attention and continuity of care, indicating a need for a policy of professional valuation and strengthening relationships with the $\mathrm{PHC}$, which demands efficiency and effort of the managers. ${ }^{5,20}$ It is also important to potentialize the communication among the professionals, making possible knowledge exchange and strengthening links of collaboration and teamwork. ${ }^{5}$

It is important to point out that the software use does not substituted the analysis and the inferences of the researchers regarding the results. From the DHC analysis, the authors defined the nomenclature of classes and showed inferences on suggested relationships by the program, based on literature and on previous knowledge on the thematic.

As limitations of this study, it should be considered the fact of not having been accessed the complete text of theses and dissertations, restricting analysis of abstracts made available in the Theses and Dissertations Catalog of CAPES. It is also important to consider that the period under analysis addresses the height of structuring and implementation process of the Brazilian IHC, since, in general, dissertations initiated from 2012 and theses from 2013 were analyzed. Thus, new studies must be undertaken seeking to follow the trends of the knowledge production about the thematic in vogue, as well as the theoreticalpractical repercussions of the researches that have already been conducted and/or that are being conducted.

\section{CONCLUSION}

Trends of the knowledge production in the academic field were identified, in Brazil, in relation to the research of the model of health-centered attention and the components of the operational structure: PHC as ordering of the network and other levels. The training of professionals for acting in networks, including academic training and the Continuou education in healthcare, with a focus on the IHN management were also found as trend.

Considering the main elements constituting the $\mathrm{IHN}$, gaps to be explored in future studies have been identified as the following components of the operational structure: logistical systems, technical and diagnostic support systems and governance system, 
in addition to the professional training guided towards the IHN, with emphasis on the integration between the services and the continuity of care. Thus, it punctuates the need of new studies to explore the advances reached and gaps still existing in each one of the categories shown in this present study.

\section{REFERENCES}

1. Mendes EV. Interview: The chronic conditions approach by the Unified Health System. Ciênc Saúde Coletiva [Internet]. 2018 Feb; [cited 2018 Mar 7]; 23(2):431-6. Available from: http://dx.doi.org/10.1590/141381232018232.16152017

2. Osnorn R, Moulds D, Schneider EC, Doty MM, Squires D, Sarnak DO. Primary Care Physicians In Ten Countries Report Challenges Caring For Patients With Complex Health Needs. Health Aff [Internet]. 2015 Dec; [cited 2018 Mar 7];34(12):2104-12. Available from:https://www.ncbi.nlm.nih.gov/ pubmed/26643631

3. Ministério da Saúde (BR). Portaria № 4.279, de 30 de dezembro de 2010. Estabelece diretrizes para a organização da Rede de Atenção à Saúde no âmbito do Sistema Único de Saúde (SUS). Brasília (DF): Ministério da Saúde; 2010.

4. Lamothe L, Sylvain C, Sit V. Multimorbidity and primary care: Emergence of new forms of network organization. Sante Publique [Internet]. 2015 Jan/ Feb; [cited 2018 Mar 15];27(Suppl. 1):S129-35. Available from: https://www. ncbi.nlm.nih.gov/pubmed/26168626

5. Vargas I, Mogollón-Pérez AS, De Paepe P, Ferreira da Silva MR, Unger JP, Vázquez ML. Barriers to healthcare coordination in market-based and decentralized public health systems: a qualitative study in healthcare networks of Colombia and Brazil. Health Policy Plan [Internet]. 2016 Jun; [cited 2018 Mar 30]; 31(6):736-48. Available from: https://www.ncbi.nlm. nih.gov/pubmed/26874327

6. Noronha JC. Redes integradas de cuidados e a pesquisa necessária. Divulg Saúde Debate [Internet]. 2014; [cited 2018 Jan 22]; 52:50-3. Available from: http://cebes.org.br/site/wp-content/uploads/2014/12/Divulgacao-52.pdf

7. Catálogo de Teses \& Dissertações - CAPES [Internet]. 2018; [cited 2017 Dec 20]. Available from: http://catalogodeteses.capes.gov.br

8. Tomicic A, Bernardi F. Between Past and Present:The Sociopsychological Constructs of Colonialism, Coloniality and Postcolonialism. Integr Psychol Behav Sci [Internet]. 2018 Mar; [cited 2018 Jan 25];52(1):152-75. Available from: https://doi.org/10.1007/s12124-017-9407-5

9. Moura SRB, Marques Junior ASSM, Oliveira TA, Nascimento LDS, Mesquita GV, Brito JNPO. Factors associated with the fall of elderly which may result in femoral fracture. Rev Enferm UFPE On Line [Internet]. 2016 Feb; [cited 2018 Jan 25]; 10(Supl. 2):720-6. Available from: https:// periodicos.ufpe.br/revistas/revistaenfermagem/article/view/11012

10. Ministério da Saúde (BR). Secretaria de Atenção à Saúde. Departamento de Atenção Básica. Política Nacional de Atenção Básica. Brasília (DF): Ministério da Saúde; 2017.

11. Cirani CBS, Campanario MA, Silva HHM. A evolução do ensino da pósgraduação senso estrito no Brasil: análise exploratória e proposições para pesquisa. Avaliação (Campinas) [Internet]. 2015; [cited 2018 Sep 2]; 20(1):163-87. Available from: http://www.scielo.br/scielo.php?pid=S141440772015000100163\&script=sci_abstract\&tlng=pt

12. Regis CG, Batista NA. The nurse in the area of collective health: conceptions and competencies. Rev Bras Enferm [Internet]. 2015 Sep/Oct; [cited 2018 Mar 8]; 68(5):830-6. Available from: http://dx.doi.org/10.1590/00347167.2015680510i

13. Gomes MHA, Martin D, Silveira C. Pertinent comments about the use of qualitative methodologies in the public health field. Interface (Botucatu) [Internet].2014 Jul/Sep; [cited 2018 Jan 25]; 18(50);469-77. Available from: https://dx.doi.org/10.1590/1807-57622014.0271

14. Taquette SR, Minayo MCS, Rodrigues AO. The perceptions of medical researchers on qualitative methodologies. Cad Saúde Pública [Internet]. 2015 Apr; [cited 2018 Jan 25]; 31(4):722-32. Available from: http://dx.doi. org/10.1590/0102-311X00094414
15. Andrade SR, Ruoff AB, Piccoli T, Schmitt MD, Ferreira A, Xavier ACA. Original article case study as a nursing research method: an integrative review. Texto Contexto Enferm [Internet]. 2017 Nov; [cited 2018 Jan 22]; 26(4):e5360016. Available from: http://dx.doi.org/10.1590/010407072017005360016

16. Mendes EV. Comentários sobre as Redes de Atenção à Saúde no SUS. Divulg Saúde Debate [Internet]. 2014; [cited 2018 Jan 22]; 52:38-49. Available from: http://cebes.org.br/site/wp-content/uploads/2014/12/ Divulgacao-52.pdf

17. Mendes A, Louvison MCP, Ianni AMZ, Leite MG, Feuerwerker LCM, Tanaka OU, et al. The process of building up regional health management in the State of São Paulo: subsidies for analysis. Saude Soc [Internet]. 2015 Apr/Jun; [cited 2018 Jan 25]; 24(2):423-37. Available from: http://dx.doi.org/10.1590/S0104-12902015000200003

18. Marinho F, Passos VMA, França EB. Novo século, novos desafios: mudança no perfil da carga de doença no Brasil de 1990 a 2010. Epidemiol Serv Saúde [Internet]. 2016; [cited 2018 May 18] 25(4):713-24. Available from: www.scielo.br/scielo.php?pid=S2237$96222016000400713 \&$ script=sci_abstract\&tIng $=p t$

19. Gonçalves CR, Cruz MT, Oliveira MP, Morais AJD, Moreira KS, Rodrigues $\mathrm{CAQ}$, et al. Human resources: critical factor for primary health networks. Saúde Debate [Internet]. 2014 Jan/Mar; [cited 2018 Mar 15]; 38(100):26-34. Available from: http://www.scielo.br/scielo. php?script=sci_arttext\&pid=S0103-11042014000100026

20. Casanova AO, Cruz MM, Giovanella L, Alves GR, Cardoso GCP. Health care networks implementation and regional governance challenges in the Legal Amazon Region: an analysis of the QualiSUS-Rede Project. Ciênc Saúde Coletiva [Internet]. 2017 Apr; [cited 2018 Jan 8]; 22(4):1209-24. Available from: http://dx.doi.org/10.1590/141381232017224.26562016

21. Medeiros CRG, Gerhardt TE. Evaluation of the Health Care Network in small towns from the perspective of management teams. Saúde Debate [Internet]. 2015 Dec; [cited 2018 Mar 8]; 39(no.spe):160-70. Available from: http://dx.doi.org/10.5935/0103-1104.2015S005201

22. Ministério da Saúde (BR). Secretaria de Atenção à Saúde. Implantação das Redes de Atenção à Saúde e outras estratégias da SAS. Brasília (DF): Ministério da Saúde; 2014. [cited 2018 Mar 7]. Available from: http:// bvsms.saude.gov.br/bvs/publicacoes/implantacao_redes_atencao_ saude_sas.pdf

23. Ministério do Planejamento, Orçamento e Gestão (Br). IPEA Objetivos de Desenvolvimento do Milênio, Relatório Nacional de Acompanhamento. Brasília (DF): IPEA; 2014.

24. Soares RS, Anjos UU, Viana RPT, Guimarães AR, Gomes LB, Araújo JSS, et al. Analysis of Changes in Maternal and Child Health Policy in a Capital of Northeastern Brazil: Dilemmas and Challenges for Care. Int Arch Med [Internet]. 2016; [cited 2018 Mar 9]; 9(279):1-9. Available from: http://dx.doi.org/10.3823/2150

25. Sally EOF, Freire MML, Ferreira HC, Berger SMD, Alvarez MM, Ribeiro CRS. Articulating gender and health: professional qualification within the scope of Rede Cegonha. Demetra [Internet]. 2017; [cited 2018 Mar 9]; 12(4):941-57. Available from: http://dx.doi.org/10.12957/ demetra.2017.28661

26. Tarrant C, Windridge K, Baker R, Freeman G, Boulton M. 'Falling through gaps': primary care patients' accounts of breakdowns in experienced continuity of care. Fam Pract [Internet]. 2015 Feb; [cited 2018 Mar 9]; 32(1):82-7. Available from: https://doi.org/10.1093/fampra/cmu077

27. Araújo DE, Merchan-Hamann E, Lima FSS, Laguardia J, Gutierrez MMU. Evaluation of health care networks: a proposal for key performance indicators. RECIIS - RECIIS [Internet]. 2016 Jul/Sep; [cited 2018 Mar 25]; 10(3):1-16. Available from: https://www.arca.fiocruz.br/handle/ icict $/ 16988$

28. Aires LCP, Santos EKA, Bruggemann OM, Backes MTS, Costa R Referência e contrarreferência do bebê egresso da unidade neonata no sistema de saúde: percepção de profissionais de saúde da Atenção Primária. Esc Anna Nery [Internet]. 2017; [cited 2018 Jun 25] 21(2):e20170028. Available from: http://eean.edu.br/detalhe_artigo. asp? $\mathrm{id}=1499$ 
29. Ferreira ML, Vargas MAO, Marques AMFB, Huhn A, Andrade SR Vargas CP. Nursing actions in reference and counter-reference in health care for persons with amputation. Cogitare Enferm [Internet] 2017; [cited 2018 Mar 9]; (22)3:e50601. Available from: http://dx.doi. org/10.5380/ce.v22i3.50601

30. McNab J, Paterson J, Fernyhough J, Hughes R. Role of the GP liaison nurse in a community health program to improve integration and coordination of services for the chronically ill. Aust J Prim Health [Internet]. 2016; [cited 2018 Mar 9];22(2):123-7. Available from: https:// www.ncbi.nlm.nih.gov/pubmed/25704062
31. Ribas EN, Bernardino E, Larocca LM, Poli Neto P, Aued GP, Silva CPC. Enfermeira de ligação: uma estratégia para a contrarreferência. Rev Bras Enferm [Internet]. 2018; [cited 2018 Aug 27]; 71(Suppl.1):546-53. Available from: http://dx.doi.org/10.1590/0034-7167-2017-0490

32. Almeida PF, Santos AM. Primary Health Care: care coordinator in regionalized networks? Rev Saúde Pública [Internet]. 2016 Dec; [cited 2018 Mar 11]; 50:80. Available from: http://dx.doi.org/10.1590/s15188787.2016050006602 